\title{
Penguatan Kemandirian Ekonomi Masyarakat Melalui Pendirian Lembaga Keuangan Mikro Berbasis Syariah Di Desa Cianaga Kabandungan Jawa Barat
}

\section{Strengthening Independence of The Local Public Economy Through Establishment of Sharia Microfinance Institution In Desa Cianaga Kabandungan Jawa Barat}

\author{
Hilwa Salma Syahdan ${ }^{1}$, Adi Rahmannur Ibnu ${ }^{2}$ \\ ${ }^{1}$ Program Studi Ekonomi Syariah Fakultas Ekonomi Islam Universitas Djuanda Bogor, Jl Tol Ciawi No. 1 \\ Kotak Pos 35 Bogor 16720, e-mail: hilwa.salma.syahdan@unida.ac.id \\ ${ }^{2}$ Program Studi Perbankan Syariah Fakultas Ekonomi Islam Universitas Djuanda Bogor, Jl Tol Ciawi No. 1 \\ Kotak Pos 35 Bogor 16720, e-mail: adi.rahmannur.ibnu@unida.ac.id
}

(Diterima: 25-06-2020; Ditelaah: 15-12-2020; Disetujui: 10-06-2021)

\begin{abstract}
Abstrak
Pengabdian kepada masyarakat ini bertujuan untuk mengembangkan kegiatan ekonomi yang difokuskan pada pendirian lembaga keuangan mikro syariah di Desa Cianaga untuk mengenalkan ekonomi syariah kepada masyarakat agar perekonomiannya menjadi lebih baik. Indikator capaian minimalnya yaitu memiliki pemahaman dasar- dasar ekonomi syariah. Target sasaran dari pendirian lembaga keuangan mikro syariah di Desa Cianaga ini adalah masyarakat di Desa Cianaga setempat. Metode yang digunakan pada pengabdian kepada masyarakat ini yaitu menggunakan metode sosialisasi efektif kepada masyarakat. Hasil dari kegiatan pengabdian masyarakat tersebut adalah membuat kesepakatan pendirian lembaga keuangan mikro syariah dalam bentuk koperasi syariah dengan nama Koperasi Syariah An-Naml.
\end{abstract}

Kata Kunci: Ekonomi Syariah, Koperasi, Sosialisasi

\begin{abstract}
College student study service aims to develop economic activities that are focused on the establishment of Islamic microfinance institutions in Desa Cianaga to introduce Islamic economics to the local public so that the economy becomes better. The minimum performance indicator is local public understanding the basics of sharia economics. The target of the establishment of Islamic microfinance institutions in Desa Cianaga is the local public in Desa Cianaga. The method used in this college student study service is to use an effective method of socialization to the local public. The result of the college student study service activities was to make an agreement to establish a sharia microfinance institution in the form of sharia cooperative named Koperasi Syariah An-Naml.
\end{abstract}

Keywords: Cooperation, Islamic Economics, Socialization

\section{PENDAHULUAN}

Desa Cianaga adalah desa yang baru berdiri di Kecamatan Kabandungan Kabupaten Sukabumi. Desa tersebut berdiri setelah dilakukan pemecahan pada Desa Mekarjaya dan Desa Tugu Bandung. Desa Cianaga ini terletak di dataran tinggi yang di kelilingi perbukitan dan gunung, salah satu gunung yang mengelilingi desa tersebut adalah Gunung Batu. Desa Cianaga memiliki luas 1.938,39 hektar dengan jumlah penduduk kurang lebih orang. Kondisi geografis desa tersebut membuat mayoritas masyarakat beternak dan bertani sebagai mata pencaharian. Hal yang sangat disayangkan di desa ini adalah sumber air 
bersih di Desa Cianaga tergolong sulit, apalagi jika mulai kemarau berkepanjangan yang mengakibatkan tanah kering. Imbasnya, sawah tidak dapat ditanami oleh petani.

Dilihat dari pembangunan desa dan sumber daya manusianya, desa tersebut tergolong desa tertinggal. Walaupun begitu, Desa Cianaga memiliki potensi sumber daya alam (SDA) yang cukup besar. Tetapi kekayaan ini tidak bisa teroptimalkan karena kendala akses infrastruktur jalan di wilayah tersebut. Ketertinggalan ini membuat kurangnya ketahanan ekonomi pada desa. Ketahanan Ekonomi adalah kondisi dinamik kehidupan perekonomian bangsa yang berisi keuletan dan ketangguhan yang mengandung kemampuan dalam mengembangkan kekuatan nasional dalam menghadapi serta mengatasi segala ancaman, rintangan, gangguan, hambatan serta tantangan yang berasal dari luar negeri dan dari dalam negeri secara langsung maupun tidak langsung untuk menjamin kelangsungan hidup perekonomian bangsa dan negara Republik Indonesia yang berdasarkan kepada Pancasila dan UUD 1945 (Marlinah, 2017).

Melihat kondisi perekonomian yang tidak menentu, semua orang berusaha untuk memperbaiki kondisi ekonominya. Begitu pun dengan masyarakat di Desa Cianaga, dalam kehidupan sehari-hari setiap individu, masyarakat secara keseluruhan akan selalu menghadapi persoalan-persoalan yang bersifat ekonomi. Pada umumnya masyarakat selalu ingin mendapatkan penghidupan yang layak setiap harinya. Dalam kehidupan sehari-hari mayarakat selalu berusaha mengerjakan pekerjaan yang dapat memampukan mereka dalam mencukupi kehidupannya, seperti yang terjadi di Desa Cianaga yakni mayoritas masyarakat bertani dan beternak untuk mencukupi kebutuhan hidupnya. Namun tidak dapat dipungkiri masyarakat membutuhkan sumber modal untuk dapat mengerjakan usaha atau pekerjaan tersebut. Lembaga pemberian kredit jelas sangat dibutuhkan masyarakat di Desa Cianaga. Sangat disayangkan, jenis-jenis kredit yang sering datang menawarkan bantuan modal bagi masyarakat adalah lembaga non bank dan rentenir.

Masyarakat memahami bahwa ada lembaga yang dapat dipinjami modal usaha yaitu bank. Tetapi, karena kekurangan pemahaman dan banyaknya syarat yang harus dipenuhi untuk meminjam dana dari bank, membuat masyarakat enggan untuk melakukannya. Hal inilah yang menyebabkan masyarakat memilih lembaga-lembaga lainnya yang memberikan kredit. Masyarakat kebanyakan menganggap proses administrasi bank terlalu rumit, membutuhkan waktu yang lama dan lokasi bank terlalu jauh dari tempat tinggal. Mereka tidak mempunyai waktu yang cukup untuk mengajukan proposal kredit kepada bank karena harus mengerjakan pekerjaan lainnya. Masih banyak ketakutan lain yang dirasakan masyarakat, seperti takut tidak sanggup mengembalikan pokok pinjaman serta bungannya, sampai takut barang jaminan atau agunan akan disita oleh pihak bank. Karena kekhawatiran itu masyarakat beranggapan kredit bank bukan untuk mereka, melainkan untuk usaha-usaha yang lebih besar, yang lebih mampu membayar pokok pinjaman beserta bungannya. Pandangan diatas menyebabkan masyarakat kurang tertarik pada kredit bank. Akhirnya masyarakat mengambil alternatif lain yang tersedia seperti rentenir. Bagi masyarakat, berhubungan dengan sumber pembiayaan informal seringkali membuat terlena dan menjadi pilihan yang menarik 
karenafaktor kemudahan mendapatkan dana secara cepat tanpa banyak syarat dengan asas saling percaya meski berbunga tinggi. Bagi rentenir, situasi ini sebenarnya menjadi peluang baik untuk memupuk keuntungan.

Lembaga-lembaga financial informal lebih atraktif dalam berpraktek mencari nasabah daripada lembaga-lembaga formal. Rentenir lebih fleksibel dalam menjalankan praktiknya bahkan mengembangkan hubungan personal dengan para nasabah, sementara bank- bank resmi bersifat "rasional" di mata masyarakat Desa Cianaga. Fleksibilitas merupakan hal penting dalam menjaga hubungan rentenir dengan nasabah. Misalnya, adanya upaya-upaya rentenir untuk memahami kondisi ekonomi nasabah sehingga tidak jarang memberikan kesempatan menunda pembayaran kredit. Rentenir dapat mengatasi "masalah kepercayaan" yang dihadapi oleh warga masyarakat yang tidak familiar dengan prosedur sistem legal. Atas dasar itu transaksi kredit dilakukan oleh kedua belah pihak atas dasar kepercayaan. Pinjam-meminjam uang yang dilakukan masyarakat di Desa Cianaga dengan rentenir ini sangat eksis, masyarakat memberikan istilah bank emok kepada para rentenir ini. Emok dalam bahasa sunda adalah sebutan untuk cara duduk perempuan, karena kegiatan pinjam-meminjam uang ini dilakukan sambil duduk emok di teras rumah warga.

Seiring berjalannya waktu, diketahui ada peminjam yang terjerat dengan lilitan hutang berbunga karena tidak mampu membayar pokok pinjaman, kemudian banyak hal yang dilakukan rentenir sampai asset peminjam tidak tersisa. Hal ini yang tidak dijadikan contoh oleh masyarakat yang lain. Tokoh masyarakat berkeinginan untuk menghentikan kegiatan pinjam-meminjam uang kepada rentenir ini dengan memahami hutang dan bunga melalui ekonomi syariah.

\section{METODE PELAKSANAAN}

Perencanaan kegiatan dilakukan oleh tim pelaksana pengabdian pada masyarakat yaitu dengan beberapa tahap, di antaranya:

1. Melakukan observasi pada masyarakat Desa Cianaga untuk mengetahui mayoritas pekerjaan tiap keluarga yang mana hal ini dapat menjadi acuan dari mana sumber dana yang dimiliki tiap keluarga.

2. Melakukan observasi kegiatan sehari- hari yang dilakukan masyarakat Desa Cianaga untuk kemudian jadi bahan catatan seperti apa aktivitas ekonomi masyarakat Desa Cianaga.

3. Melakukan pendekatan diskusi dengan tokoh masyarakat mengenai kebiasaan melakukan transaksi dengan bank emok yang dilakukan masyarakat Desa Cianaga.

4. Melakukan sosialisasi kepada masyarakat Desa Cianaga untuk meningkatkan pemahaman ekonomi syariah masyarakat Desa Cianaga.

5. Membuat kesepakatan mengenai pendirian koperasi syariah yang dilakukan oleh tokoh masyarakat Desa Cianaga dalam bentuk berita acara.

Pelaksanaan kegiatan dilakukan sesuai dengan perencanaan kegiatan, sosialisasi dilakukan sebanyak 5 kali, di antaranya: 
1. Sabtu, 25 Agustus 2018, di Masjid Jami 'Al Istiqamah dengan tema Peningkatan Pemahaman Masyarakat terkait dengan Akad Syariah melalui Program Sosialisasi Ekonomi Syariah.

2. Kamis, 30 Agustus 2018, di Masjid Jami Nurul Hikmah dengan tema Peningkatan Pemahaman Masyarakat Mengenai Fiqh Muamalah Melalui Sosialisasi Ekonomi Islam.

3. Minggu, 2 September 2018, di Masjid Jaami Nurul Hikmah dengan tema Peningkatan Pemahaman Masyarakat Mengenai Fiqh Muamalah Melalui Sosialisasi Ekonomi Islam

4. Senin, 3 September 2018, di Masjid Jami Nurul Hikmah dengan tema Peningkatan Pemahaman Masyarakat terkait dengan Akad Syariah melalui Program Sosialisasi Ekonomi Syariah

5. Jumat, 7 September 2018, di MI Nurul Mukhlasin dengan tema Peningkatan Pemahaman Masyarakat Mnegenai Fiqh Muamalah Melalui Sosialisasi Ekonomi Islam.

\section{HASIL \& PEMBAHASAN}

Pelaksanaan dari rencana kegiatan diakhiri dengan duduk bersama perwakilan pemerintah desa dan tokoh masyarakat untuk membentuk koperasi syariah di Desa Cianaga. Dalam pertemuan ini, salah satu tokoh masyarakat yaitu Bapak Noerman Sahaya AQ, memberikan nama pada koperasi syariah yang akan dibentuk, yaitu Koperasi Syariah An- Naml. An-Naml adalah nama surat ke- 27 dalam Al-Quran yang artinya semut. Dinamai dengan An-Naml yang berarti semut, karena pada ayat 18 dan 19 terdapat perkataan An-Naml (semut), di mana raja semut mengatakan kepada anak buahnya agar masuk sarangnya masing-masing, supaya jangan terlindas oleh Nabi Sulaiman dan tentaranya yang akan melewati tempat itu.

Semut digambarkan sebagai serangga yang dikenal memiliki sikap gotong royong dan rapi dalam berorganisasi. Diharapkan, Koperasi Syariah An-Naml mampu bersikap seperti semut yang tidak kenal lelah dan putus asa walaupun telah berkali-kali terjatuh, entah karena tertiup angin ataupun hal lainnya. Sungguh semut akan terus mencoba sebanyak apapun gagal sampai berhasil mencapai keinginan. Selain peserta pertemuan sepakat dalam penamaan koperasi syariah, peserta juga menyepakati 3 hal lainnya yaitu; Koperasi Syariah An-Naml bermaksud untuk melakukan kegiatan simpan, pinjam, dan pembiayaan secara syariah; Koperasi Syariah An-Naml akan mengawali kegiatan di Desa Cianaga, Desa Cianaga; dan Koperasi Syariah An- Naml akan menyusun Struktur Organisasi, Visi dan Misi serta Anggaran Dasar Rumah Tangga dalam waktu dekat. Kesepakatan ini tertuang dalam berita acara yang ditandatangani oleh Bapak Odang Abidin, S.Ag selaku Kepala Desa Cianaga, Bapak Noerman Sahaya AQ selaku tokoh masyarakat, dan Muhammad Suhendar selaku Ketua tim pengabdi.

Program ini diharapkan dapat berjalan dengan baik, yang mana sampai laporan ini dibuat, telah dilakukan komunikasi dengan kepala desa, pemuka agama, dan masyarakat Desa Cianaga guna membentuk struktur organisasi dan menyamakan tujuan pendirian koperasi syariah. Tim pengabdian pada masyarakat juga telah membuat logo yang disetujui oleh pemangku kepentingan. Dalam logo ini terdapat warna kuning yang 
mengartikan kesejahteraan, diharapkan masyarakat Desa Cianaga disejahterakan dengan hadirnya koperasi syariah ini. Warna hijau menggambarkan cara pandang yang islami, dimana koperasi yang berdiri ini adalah koperasi syariah, ditambah gambar AlQuran menunjukkan bahwa masyarakat Desa Cianaga menjunjung tinggi nilai-nilai islami dan menjauhkan diri dari hal-hal yang dilarang agama. Sedangkan, gambar semut menggambarkan sikap gotong royong. Diharapkan masyarakat Desa Cianaga dalam meningkatkan ekonomi masyarakat dengan cara yang syariah pun bergotong royong. Diawali dengan menabung, kemudian meminjam untuk pembiayaan dan pengembalian pinjaman dengan cara yang syariah sehingga keuangan masyarakat dijauhkan dari riba dan aktivitas ekonomi yang dilarang agama Islam.

\section{KESIMPULAN}

Keberhasilan program ini sampai pada kesepakatan pembentukan Koperasi Syariah AnNaml yang dilakukan antara tim pengabdian pada masyarakat dan pemangku kepentingan yaitu pemerintah desa dan tokoh masyarakat, sebelum dilakukan kesepakatan yang tertuang dalam berita acara, telah dilakukan observasi dan sosialisasi sebanyak 5 kali kepada masyarakat Desa Cianaga. Tim pengabdian pada masyarakat berhasil melakukan sosialisasi dua arah kepada masyarakat yang mana meningkatkan pengetahuan masyarakat terhadap haramnya riba dalam agama Islam. Selain itu, tim pengabdian pada masyarakat berhasil membantu mendorong pemerintah desa dan tokoh masyarakat untuk menghadirkan wadah alternatif bagi masyarakat Desa Cianaga yang diharapkan dapat menjadi solusi bagi masyarakat dalam melakukan aktivitas ekonomi di antaranya menabung dan meminjam uang.

\section{DAFTAR PUSTAKA}

Koperasi Syariah. (2014, Maret 18). Diakses pada September 25, 2018, from www.koperasisyariah.com

Marlinah, L. (2017). Meningkatkan Ketahanan Ekonomi Nasional Melalui Pengembangan Ekonomi Kreatif. Cakrawala Jurnal Humaniora Universitas Bina Sarana Informatika. Pemerintah Desa Cianaga. (2015). Profil Desa Cianaga. Kabupaten Sukabumi 